\title{
Granulocyte Colony-Stimulating Factor Receptor
}

National Cancer Institute

\section{Source}

National Cancer Institute. Granulocyte Colony-Stimulating Factor Receptor. NCI

Thesaurus. Code C26079.

Granulocyte colony-stimulating factor receptor precursor (836 aa, $\sim 92 \mathrm{kDa}$ ) is encoded by the human CSF3R gene. This protein plays a role in granulocyte differentiation. 